$\begin{array}{ll}\text { Research Square } & \begin{array}{l}\text { Preprints are preliminary reports that have not undergone peer review. } \\ \text { They should not be considered conclusive, used to inform clinical practice, } \\ \text { or referenced by the media as validated information. }\end{array}\end{array}$

\title{
Prevalence of Helicobacter Pylori Genotypes and Their Association With Upper Gastrointestinal Diseases: a Cross Sectional Study in Southern Iran
}

Rahim Raufi

Jahrom University of Medical Science

Reza Shahriarirad

Shiraz University of Medical Sciences

SeyedehMaryam Pishva

Shiraz University of Medical Sciences

Nikta Taghipour ( $\nabla$ niktataghipoor114@gmail.com)

Jahrom University of Medical Science https://orcid.org/0000-0002-7726-4368

\section{Research}

Keywords: Prevalence, Helicobacter pylori, genotype, Gastrointestinal diseases, Iran

Posted Date: January 5th, 2021

DOl: https://doi.org/10.21203/rs.3.rs-137967/v1

License: () (1) This work is licensed under a Creative Commons Attribution 4.0 International License. Read Full License 


\section{Abstract}

Background: Investigating the prevalence of vacuolating cytotoxin (vacA), cytotoxin associated gene A (cagA), glm M genotypes, and subtypes of vacA of Helicobacter pylori (H. pylori) isolate in Jahrom, Southern Iran. DNA extracted from H. pylori samples retrieved from gastric biopsy isolated from 113 dyspeptic patients with positive rapid urease test (RUT). Genotyping was done by polymerase chain reaction (PCR) technique, using primers for vacA (s1a, s1b, s1c, s1, $\mathrm{s} 2, \mathrm{~m} 2$, and m1), cagA, and glmM. Endoscopy was done for all the patients to screen upper gastrointestinal (GI) disorders.

Results: GlmM was detected in $100 \%$ of the cases. VacA subtypes s1am2, s2m2, s1a, s1b, and s1c were detected in $27.9 \%, 25.6 \%, 50 \%, 3.5 \%$ and $2.4 \%$ of the isolates, respectively, while cagA was detected in $60.5 \%$ of the isolates. VacA alleles $\mathrm{m} 1$, s1, and s 2 were detected in $54 \%, 50 \%$, and $44 \%$ of isolates respectively. Also, $60.5 \%$ of the isolates were cagA-vacA-positive. A significant correlation was observed between vacAs $1 \mathrm{bm} 1$ and gastroesophageal reflux disease (GERD) and glmM and normal esophagus. The presence of vacAs1bm1 and vacAs1bm2 has a significant association with gastric erythema. The presence of cagA showed a significant association with normal esophagus and hiatal hernia.

Conclusions: In our research, the number of glmM and cagA positive isolates is higher among other genotypes and cagA is correlated with hiatal hernia, and normal esophageal finding is correlated with glmM genotype. There was no association between age or sex of the patients and bacterial genotype.

\section{Background}

Helicobacter pylori (H. pylori) is a gram-negative bacillus and one of the most common bacterial infections which affect nearly half of the world's population, which has naturally colonized humans for at least 100,000 years, and probably throughout human evolution [1]. H. pylori colonize the stomach in approximately $50 \%$ of the world's human population. In the United States and other developed countries, the prevalence of $\mathrm{H}$. pylori is approximately $30 \%$ of the population [2]. Moreover, DNA-level analyses have indicated that $\mathrm{H}$. pylori are one of the most genetically diverse bacterial species [3].

The sequencing of the H. pylori genome in 1997 has led to considerable progress in the understanding of the biology of this organism. H. pylori are considered an important etiological agent in the development of gastritis, peptic ulcers, and gastric carcinoma [4, 5]. Colonization with this organism is the main risk factor for peptic ulceration as well as for gastric adenocarcinoma and gastric mucosa-associated lymphoid tissue (MALT) lymphoma [6]. H. pylori infection is virtually always associated with chronic active gastritis, but less than $15 \%$ of patients develop peptic ulcer disease (PUD), gastric adenocarcinoma, or gastric lymphoma [7]. Studies suggested that more than $90 \%$ of duodenal ulcers (DU) and $85 \%$ of gastric ulcers (GU) are associated with $\mathrm{H}$. pylori [7]. There is a strong connection between $\mathrm{H}$. pylori and gastric lymphoma. $\mathrm{H}$. pylori antigen stimulates T-cells which promotes B-cell proliferation, leading to low-grade gastric MALT lymphoma. Eradication of H. pylori can result in regression or cure of this lymphoma [8].

The clinical outcome following infection with this pathogen has been related to environmental conditions, host immunological factors, and microorganism virulence [9]. H. pylori genotypes and their geographic distribution are linked to the severity of PUD [10, 11]. The VacA protein induces vacuolation and apoptotic processes in epithelial cells, as well as immunosuppressive actions in immunological cells [12].

The vacA, cagA, and glmM are the most commonly studied virulence factors of $\mathrm{H}$. pylori, and in this study, we investigate the prevalence of the genotypes and their association with $\mathrm{GI}$ pathologies.

The clinical outcome of this bacterial infection seems to be influenced by the distribution of the above-mentioned pathogenic factors in H. pylori strains [13]. Due to the lack of H. pylori genotyping in southern Iran, in this study we investigate H. pylori genotyping in Jahrom, southern Iran. Furthermore, we aim to establish the main virulence strain and its association with clinical outcomes.

\section{Results}

A total of 113 patients with an average age of 39.15 (SD:16.18, range 13-89) were studied which consisted of 44 (38.9\%) male and 69 (61.1\%) female patients. Furthermore, $15.9 \%$ of the patients were smokers. Based on PCR evaluation for H. pylori, 86 samples out of 113 (76.1\%) patients were positive. Table 1 demonstrates the study population characteristics. 
Table 1

Characteristic of patients with persistent gastrointestinal problems in our study

\begin{tabular}{|c|c|c|c|}
\hline Variable & & Frequency $n=113$ & Percentage \\
\hline \multirow[t]{2}{*}{ Gender } & Male & 44 & 38.9 \\
\hline & Female & 69 & 61.1 \\
\hline \multicolumn{2}{|l|}{ Positive PCR for H.Pylori } & 86 & 76.1 \\
\hline \multirow[t]{4}{*}{ Endoscopy finding } & NUD & 52 & 46 \\
\hline & Erosive gastropathy & 47 & 41.6 \\
\hline & GU & 3 & 2.7 \\
\hline & DU & 11 & 9.7 \\
\hline \multirow[t]{2}{*}{ Erythema in NUD } & Antrum & 45 & 39.8 \\
\hline & Antrum with extension to body or fundus & 6 & 5.3 \\
\hline \multirow[t]{2}{*}{ Edema in NUD } & Antrum & 4 & 5.3 \\
\hline & Antrum with extension to body or fundus & 2 & 1.8 \\
\hline \multirow[t]{2}{*}{ Nodularity } & Antrum & 5 & 4.4 \\
\hline & Antrum with extension to body or fundus & 0 & 0 \\
\hline \multirow[t]{4}{*}{ Esophageal finding } & Esophagitis & 9 & 8 \\
\hline & GERD & 5 & 4.4 \\
\hline & Hiatal hernia & 57 & 50.4 \\
\hline & Normal & 42 & 37.2 \\
\hline
\end{tabular}

Vac A gene was present in all $\mathrm{H}$. pylori samples and was accompanied by the Cag A gene in $60.5 \%$ of samples. Table 2 demonstrates the result of different genotypes that we found in our samples.

Table 2

Distribution of H. pylori genotypes in southern Iran $n=86$

\begin{tabular}{|lllll|}
\hline Genotypes & Positive & \multicolumn{3}{c|}{ Negative } \\
\cline { 2 - 5 } & Frequency & Percentage & Frequency & Percentage \\
\hline Vac Am1 & 39 & 45.3 & 47 & 54.7 \\
\hline Vac Am2 & 47 & 54.7 & 39 & 45.3 \\
\hline Vac As1a & 43 & 50 & 43 & 50 \\
\hline Vac As1b & 3 & 3.5 & 83 & 96.5 \\
\hline Vac As1c & 2 & 2.3 & 84 & 97.7 \\
\hline Vac As2 & 38 & 44.2 & 48 & 55.8 \\
\hline Cag a & 52 & 60.5 & 34 & 39.5 \\
\hline GIm m & 86 & 100 & 0 & 0 \\
\hline
\end{tabular}

The vac A gene and its subtypes distribution are shown in Table 3. The most common genotypes were vac As 1 am 2 with a prevalence of $28 \%$ then vac As2bm2 and vac As1am1. 
Table 3

Distribution of the vac A gene and its subtypes in southern Iran.

\begin{tabular}{|lllll|}
\hline Genotypes & Positive & \multicolumn{3}{c|}{ Negative } \\
\cline { 2 - 5 } & Frequency & Percentage & Frequency & Percentage \\
\hline vacAs1am1 & 19 & $22.1 \%$ & 67 & 77.9 \\
\hline vacAs1am2 & 24 & 27.9 & 62 & 72.1 \\
\hline vacAs1bm1 & 2 & 2.3 & 84 & 97.7 \\
\hline vacAs1bm2 & 1 & 1.2 & 85 & 98.8 \\
\hline vacAs1cm1 & 1 & 1.2 & 85 & 98.8 \\
\hline vacAs1cm2 & 1 & 1.2 & 85 & 98.8 \\
\hline vacAs2m1 & 16 & 18.6 & 70 & 81.4 \\
\hline vacAs2m2 & 22 & 25.6 & 64 & 74.4 \\
\hline
\end{tabular}

The patients were divided into 4 groups based on their endoscopic findings: a) Non-ulcer dyspepsia (NUD): no erosion, but erythema, edema, or nodularity was observed. The location of these findings in the stomach was also studied. b) Erosive gastropathy c) Gastric Ulcer (GU) d) Duodenal ulcer (DU).

Out of 52 patients with NUD, 51 of them had gastric erythema, 6 of them had gastric edema and 5 patients had gastric nodularity. The erythema was located in the antrum for $39.8 \%$ of them. Out of 6 patients with edema, $5.3 \%$ had antrum involvement.

Esophageal findings of patients are shown in Table 1. Esophagitis in $8 \%$ of the cases, Gastroesophageal reflux in $4.4 \%$ of the cases, and hiatal hernia in $50.4 \%$ of the cases.

Table 4 shows the relationship between the different H. pylori genotypes and age, gender, smoking, gastric endoscopy, and esophageal findings. 
Table 4

Relationship between different H.pylori genotypes and variables in our study

\begin{tabular}{|c|c|c|c|c|c|c|c|c|c|c|c|c|c|c|}
\hline \multirow[t]{2}{*}{ Variable } & & \multicolumn{13}{|c|}{ Genotype $n=86$} \\
\hline & & $\begin{array}{l}\text { S1am1 } \\
n=19\end{array}$ & $\mathbf{P}$ & $\begin{array}{l}\text { S1am2 } \\
n=24\end{array}$ & $\mathbf{P}$ & $\begin{array}{l}\text { S1bm1 } \\
n=2\end{array}$ & $\mathbf{P}$ & $\begin{array}{l}\text { s1bm2 } \\
n=1\end{array}$ & $\mathbf{P}$ & $\begin{array}{l}\mathrm{S} 1 \mathrm{~cm} 1 \\
n=1\end{array}$ & $\mathbf{P}$ & $\begin{array}{l}\mathrm{S} 1 \mathrm{~cm} 2 \\
n=1\end{array}$ & $\mathbf{P}$ & $\begin{array}{l}S 2 m 1 \\
n=16\end{array}$ \\
\hline \multicolumn{2}{|c|}{ Mean Age (SD) } & $\begin{array}{l}33.6 \\
(10.8)\end{array}$ & - & $\begin{array}{l}39.2 \\
(14.3)\end{array}$ & - & $\begin{array}{l}40.5 \\
(27.6)\end{array}$ & - & $29(0)$ & - & $70(0)$ & - & $60(0)$ & - & $\begin{array}{l}38.1 \\
(17.2)\end{array}$ \\
\hline \multirow[t]{2}{*}{ Gender } & Male & $\begin{array}{l}7 \\
(36.8)\end{array}$ & 1 & $\begin{array}{l}9 \\
(37.5)\end{array}$ & 1 & $2(100)$ & 0.149 & $1(100)$ & 0.389 & $\begin{array}{l}1 \\
(100)\end{array}$ & 0.389 & $\begin{array}{l}1 \\
(100)\end{array}$ & 0.389 & $4(25)$ \\
\hline & Female & $\begin{array}{l}12 \\
(63.2)\end{array}$ & & $\begin{array}{l}15 \\
(62.5)\end{array}$ & & $0(0)$ & & $0(0)$ & & $0(0)$ & & $0(0)$ & & $\begin{array}{l}12 \\
(75)\end{array}$ \\
\hline \multirow[t]{2}{*}{ Smoker } & Yes & $\begin{array}{l}3 \\
(15.8)\end{array}$ & 1 & $3(12.5)$ & 0.76 & $1(50)$ & 0.294 & $0(0)$ & 1 & $0(0)$ & 1 & $\begin{array}{l}1 \\
(100)\end{array}$ & 0.159 & $\begin{array}{l}3 \\
(18.8)\end{array}$ \\
\hline & No & $\begin{array}{l}16 \\
(84.2)\end{array}$ & & $\begin{array}{l}21 \\
(87.5)\end{array}$ & & $1(50)$ & & $1(100)$ & & $\begin{array}{l}1 \\
(100)\end{array}$ & & $0(0)$ & & $\begin{array}{l}13 \\
(81.2)\end{array}$ \\
\hline \multirow[t]{4}{*}{ Endoscopy } & $N U D$ & $\begin{array}{l}7 \\
(36.8)\end{array}$ & 0.454 & $\begin{array}{l}13 \\
(54.2)\end{array}$ & 0.489 & $1(50)$ & 1 & $1(100)$ & 0.46 & $\begin{array}{l}1 \\
(100)\end{array}$ & 0.46 & $0(0)$ & 1 & $8(50)$ \\
\hline & $\begin{array}{l}\text { Erosive } \\
\text { gastropathy }\end{array}$ & $\begin{array}{l}10 \\
(52.6)\end{array}$ & 0.316 & $6(25)$ & 0.101 & $1(50)$ & 1 & $0(0)$ & 1 & $0(0)$ & 1 & $0(0)$ & 1 & $\begin{array}{l}7 \\
(43.8)\end{array}$ \\
\hline & GU & $0(0)$ & 1 & $2(8.3)$ & 0.114 & $0(0)$ & 1 & $0(0)$ & 1 & $0(0)$ & 1 & $0(0)$ & 1 & $0(0)$ \\
\hline & $D U$ & $\begin{array}{l}2 \\
(10.5)\end{array}$ & 1 & $\begin{array}{l}3 \\
(12.5)\end{array}$ & 0.698 & $0(0)$ & 1 & $0(0)$ & 1 & $0(0)$ & 1 & $\begin{array}{l}1 \\
(100)\end{array}$ & 0.097 & $\begin{array}{l}1 \\
(6.2)\end{array}$ \\
\hline \multirow[t]{4}{*}{$\begin{array}{l}\text { Esophageal } \\
\text { Findings }\end{array}$} & Esophagitis & $0(0)$ & 0.353 & $\begin{array}{l}3 \\
(12.5)\end{array}$ & 0.398 & $0(0)$ & 1 & $0(0)$ & 1 & $0(0)$ & 1 & $0(0)$ & 1 & $\begin{array}{l}2 \\
(12.5)\end{array}$ \\
\hline & GERD & $1(5.3)$ & 1 & $1(4.2)$ & 1 & $2(100)$ & 0.002 & $0(0)$ & 1 & $0(0)$ & 1 & $0(0)$ & 1 & $0(0)$ \\
\hline & $\begin{array}{l}\text { Hiatal } \\
\text { Hernia }\end{array}$ & $\begin{array}{l}9 \\
(47.4)\end{array}$ & 0.806 & $\begin{array}{l}10 \\
(41.7)\end{array}$ & 0.366 & $1(50)$ & 1 & $0(0)$ & 0.496 & $0(0)$ & 0.496 & $\begin{array}{l}1 \\
(100)\end{array}$ & 1 & $\begin{array}{l}7 \\
(43.8)\end{array}$ \\
\hline & Normal & $\begin{array}{l}9 \\
(47.4)\end{array}$ & 0.439 & $\begin{array}{l}10 \\
(41.7)\end{array}$ & 0.813 & $0(0)$ & 0.524 & $1(100)$ & 0.381 & $\begin{array}{l}1 \\
(100)\end{array}$ & 0.381 & $0(0)$ & 1 & $\begin{array}{l}7 \\
(43.8)\end{array}$ \\
\hline
\end{tabular}

PCR: polymerase chain reaction; H,pylori: Helicobacter Pylori; NUD: Non-ulcer dyspepsia; GU: Gastric ulcer; DU: Duodenal ulcer; GERD: Gastroesophageal reflu

There was no significant relationship found between the age, gender, smoking of the patients, and the genotype of H. pylori they were colonized with. However, the Vac As $1 \mathrm{~cm} 1$ genotype had the highest mean age $(70 \pm 0)$ and the vacAs1am1 gene had the lowest mean age (33.6 \pm 10.8$)$. Also, there is no relationship between gastric endoscopy finding and the genotype of $\mathrm{H}$. pylori.

Based on Table 4, there is a significant correlation among Vac As1bm1 genotype and GERD $(p=0.002)$; Cag A genotype and hiatal hernia ( $p=0.02)$; Cag A genotype and normal esophagus; GIm M genotype and normal esophagus $(p=0.02)$. We found that genotype vac As 1 bm2 is linked with gastric edema $(P>$ 0.001 ); however, there is only 1 person in this group.

\section{Discussion}

H. pylori genotypes, environmental and epidemiological factors can play a role in its pathogenicity. The genetic diversity and epigenetic modifications of $\mathrm{H}$. pylori give rise to the different levels of pathogenicity. Several studies have shown that the incidence and/or severity of gastroduodenal pathologies related to $\mathrm{H}$. pylori may vary between geographic areas, such as studies have shown genotype of $\mathrm{H}$. pylori in Europe differs from South-East Asia but is the same for the North of Iran and Uzbekistan $[14,15]$. The predominant H. pylori strain circulating among geographic locations differs with regard to the genomic structure [16]. The present study reports common H. pylori genotypes in Jahrom, Iran, and their clinical relevance.

The vacA gene was present in all H. pylori strains and it is a useful marker in predicting disease outcome [17]. The vacA strain's structure determines its in vitro cytotoxic activity, with $\mathrm{m} 1$ vacA type being more active than $\mathrm{m} 2$ type, s1a more active than $\mathrm{s} 1 \mathrm{~b}$, and $\mathrm{s} 2$ vacA not producing detectable activity [18]. We found an apparent correlation between vacAs1bm1 positive cases and GERD $(P=0.002)$. Genotype vacA s1/m2 is a dominant $H$.pylori genotype in Iran, but no relationships were found between these genotypes and clinical outcomes. In this study, we found the vac $\mathrm{A}$ gene of $\mathrm{H}$. pylori has 8 different combinations with its subtypes, and their prevalence are; vacAs1am1 (22.1\%), vacAs1am2 (27.9\%), vacAs1bm1 (2.3\%), vacAs1bm2 (1.2\%), vacAs1cm1 (1.2\%), vacAs1cm2 (1.2\%), vacAs $2 \mathrm{~m} 1$ (18.6\%) and vacAs2m2 (25.6\%). The most common genotype is vac A s1am2 with a prevalence of approximately $28 \%$; however, $\mathrm{S} 1 \mathrm{~m} 1 \mathrm{was}$ the most common genotype in some research studies conducted on Afghan, Iranian, Turkish, and Thai patients [19-22], however in our research prevalence of $\mathrm{s} 1 \mathrm{~m} 1(22.1 \%)$ is the third common genotype. A study from Shiraz, southern Iran reported that vacA-positive strains were more frequently found in PUD patients than in NUD patients [23]. Another study in Tehran reported that the vacA s1 genotype was detected in $79 \%$ and $68 \%$ of patients with PUD and NUD, respectively [24]. However, in our study, we didn't observe any correlation between any vacA subtypes and PUD or NUD. 
The cagA toxin can induce severe inflammation of gastric mucosa and is related to peptic ulcer and gastric cancer [18]. Based on literature regarding $\mathrm{H}$. pylori genotype in Iran and around the world, the prevalence of cag A genotype varies in different areas. The prevalence of cag A genotype is high based on studies conducted on Iranian and Iraqi patients [24]. However, in research conducted on Malaysian and Jordanian patients, the prevalence of cag A is relatively low $[25,26]$. The cagA was present in $60-70 \%$ of isolates from the Western population [27]. In our research cagA was present in $60.5 \%$ of isolates. We observed a significant relationship between cag $A$ and hiatal hernia $(P=0.02)$. Several European and North American studies have shown that infection with cagA-positive $\mathrm{H}$. pylori strains also increases the risk for atrophic gastritis and gastric cancer [27]. However, several studies in Asian populations did not confirm these relationships, indicating that there are important geographic differences, which is consistent with our research finding [28].

The association of the cagA-positive, vacA s1 genotypes with peptic ulcer disease (PUD) and gastric cancer was reported in Western countries, which was not consistent with our research and a research in East Asian countries [16]. Patients infected with less virulent genotypes are more likely to have mild gastritis throughout their entire life, whereas patients infected with more virulent genotypes have a higher probability of developing peptic ulcer disease, atrophic gastritis, and eventually gastric carcinoma [28].

Our results showed that the most common allele in our isolates is m2 (55.9\%), and s1 (55.9\%), then s2 (44.2\%). Although in other research on Iranian and Afghan patients [21] the most common allele is s1.

\section{Conclusions}

In this study, we analysed the H. pylori gene and its association with clinical outcomes. Our data suggested that cagA is associated with normal esophageal findings, which support the hypothesis of virulent strains may provide some protection for the esophagus. Furthermore, no significant relationship was observed between the $\mathrm{H}$. pylori gene and patients' characteristics (such as age, sex, smoking status). This study provides the first report of H. pylori gene diversity in Jahrom, Iran, and serves as an epidemiological tool for future studies on this bacterium to better understand the clinical outcome of this pathogen.

\section{Materials And Methods \\ Patients}

We used a descriptive cross-sectional method in this study. Patients who visited Jahrom's Honary clinic (a city in Fars province, south of Iran) with persistent gastrointestinal problems, above 18 years of age, and did not respond to 6 months treatment with proton pump inhibitor (PPI), and positive rapid urease test (RUT) were studied. Esophagogastroduodenoscopy (EGD) and 2 biopsy samples were retrieved from their stomach antrum.

This study was approved by the ethics committee of Jahrom University of Medical Sciences. All the participants were informed about the study and signed consent forms and reassured their confidentiality.

The patients included must have dyspepsia and positive RUT at the time of EGD. Patients were excluded from this study if they had a history of antibiotic therapy in the last month or if they used a PPI or $\mathrm{H} 2$ blocker in the last week.

\section{DNA Extraction and PCR}

Two samples were retrieved by EGD from every patient gastric antrum and with microbiology techniques one sample was used for RUT and another was kept on a transport medium which contains; Agar $1.3 \mathrm{~g} / \mathrm{L}$ and yeast extract $3 \%$. If the urease test came positive, PCR was conducted for the second sample. We used fermentas Company kits for DNA extraction.

The primers that were used for genotyping and PCR conditions are shown in Table 5. The following cycle conditions were used: for vacA: 35 cycles of 1 min at $94{ }^{\circ} \mathrm{C}, 1 \mathrm{~min}$ at $53^{\circ} \mathrm{C}$, and $1 \mathrm{~min}$ at $72{ }^{\circ} \mathrm{C}$; for cagA: $1 \mathrm{~min}$ at $94{ }^{\circ} \mathrm{C}, 1 \mathrm{~min}$ at $56^{\circ} \mathrm{C}$, and $1 \mathrm{~min}$ at $72{ }^{\circ} \mathrm{C}$; for glmM: $1 \mathrm{~min}$ at $93^{\circ} \mathrm{C}, 1 \mathrm{~min}$ at $55^{\circ} \mathrm{C}$, and $1 \mathrm{~min}$ at $72^{\circ} \mathrm{C}$. GImM PCR product has 294 bp, cagA has $298 \mathrm{bp}$ and vacA subtypes (s1/s2, s1a, s1b, s1c, m1/m2) has 259, 286, 190, 187, 213, 567 and 642 bp respectively. 
Table 5

Primer sequence and polymerase chain reaction (PCR) conditions

\begin{tabular}{|c|c|c|c|c|}
\hline Genes & Primer sequence $\left(5^{\prime} \rightarrow 3^{\prime}\right)$ & PCR product (bp) & PCR conditions & References \\
\hline \multirow[t]{2}{*}{ glmM } & AAGCTTTTAGGGGTGTTAGGGGTTT & \multirow[t]{2}{*}{294} & \multirow[t]{2}{*}{$93^{\circ} \mathrm{C}, 1 \mathrm{~min} ; 55^{\circ} \mathrm{C}, 1 \mathrm{~min} ; 72^{\circ} \mathrm{C}, 1 \mathrm{~min}$ (35 cycles) } & \multirow[t]{2}{*}{ [29] } \\
\hline & AAGCTTACTTTCTAACACTAACGC & & & \\
\hline \multicolumn{5}{|l|}{ vacA } \\
\hline \multirow[t]{2}{*}{ s1/s2 } & ATGGAAATACAACAAACACAC & \multirow[t]{2}{*}{$259 / 286$} & \multirow[t]{2}{*}{$94^{\circ} \mathrm{C}, 1 \mathrm{~min} ; 52^{\circ} \mathrm{C}, 1 \mathrm{~min} ; 72^{\circ} \mathrm{C}, 1 \mathrm{~min}(35$ cycles $)$} & \multirow[t]{2}{*}[18,30]{} \\
\hline & CTGCTTGAATGCGCCAAAC & & & \\
\hline \multirow[t]{2}{*}{ s1a } & GTCAGCATCACACCGCAAC & \multirow[t]{2}{*}{190} & \multirow[t]{2}{*}{$94^{\circ} \mathrm{C}, 1 \mathrm{~min} ; 52^{\circ} \mathrm{C}, 1 \mathrm{~min} ; 72^{\circ} \mathrm{C}, 1 \mathrm{~min}$ (35 cycles) } & \multirow[t]{2}{*}{ [18] } \\
\hline & CTGCTTGAATGCGCCAAAC & & & \\
\hline \multirow[t]{2}{*}{ s1b } & AGCGCCATACCGCAAGAG & \multirow[t]{2}{*}{187} & \multirow[t]{2}{*}{$94^{\circ} \mathrm{C}, 1 \mathrm{~min} ; 52{ }^{\circ} \mathrm{C}, 1 \mathrm{~min} ; 72^{\circ} \mathrm{C}, 1 \mathrm{~min}(35$ cycles $)$} & \multirow[t]{2}{*}{ [18] } \\
\hline & CTGCTTGAATGCGCCAAAC & & & \\
\hline \multirow[t]{2}{*}{ s1c } & CTCTCGCTTTAGTGGGGYT & \multirow[t]{2}{*}{213} & \multirow[t]{2}{*}{$94^{\circ} \mathrm{C}, 1 \mathrm{~min} ; 52^{\circ} \mathrm{C}, 1 \mathrm{~min} ; 72^{\circ} \mathrm{C}, 1 \mathrm{~min}$ (35 cycles) } & \multirow[t]{2}{*}{ [31] } \\
\hline & CTGCTTGAATGCGCCAAAC & & & \\
\hline \multirow[t]{2}{*}{$\mathrm{m} 1 / \mathrm{m} 2$} & CAATCTGTCCAATCAAGCGAG & \multirow[t]{2}{*}{$567 / 642$} & \multirow[t]{2}{*}{$94^{\circ} \mathrm{C}, 1 \mathrm{~min} ; 52^{\circ} \mathrm{C}, 1 \mathrm{~min} ; 72^{\circ} \mathrm{C}, 1 \mathrm{~min}(35$ cycles $)$} & \multirow[t]{2}{*}{ [18] } \\
\hline & GCGTCAAAATAATTCCAAGG & & & \\
\hline \multirow[t]{2}{*}{$\operatorname{cag} \mathrm{A}$} & ATAATGCTAAATTAGACAACTTGAGCGA & \multirow[t]{2}{*}{298} & \multirow[t]{2}{*}{$94^{\circ} \mathrm{C}, 1 \mathrm{~min} ; 60^{\circ} \mathrm{C}, 1 \mathrm{~min} ; 72^{\circ} \mathrm{C}, 1 \mathrm{~min}$ ( 45 cycles) } & \multirow[t]{2}{*}{ [32] } \\
\hline & TTAGAATAATCAACAAACATCACGCCAT & & & \\
\hline
\end{tabular}

\section{Data analysis}

Based on Prevalence of $69 \%, \mathrm{ci}=95 \%$, absolute error $=80 \%$ and population $(\mathrm{N})$ of $1,000,000$, a sample size of $n=113$ was calculated [33]. Data collected from this study were analyzed using chi-square, fisher's exact test and spearman methods, and SPSS software ver 22.0.

\section{Abbreviations}

vacA: Vacuolating cytotoxin A; cagA: Cytotoxin associated gene A; H. pylori: Helicobacter pylori; RUT: Rapid urease test; PCR: Polymerase chain reaction; GI: Gastrointestinal; GERD: Gastroesophageal reflux disease; MALT: Mucosa-associated lymphoid tissue; PUD: Peptic ulcer disease; DU: Duodenal ulcers; GU: Gastric ulcers; NUD: Non-ulcer dyspepsia; PPI: Proton pump inhibitor; EGD: Esophagogastroduodenoscopy.

\section{Declarations}

\section{Ethical approval of the study}

Written inform consent was obtained from the patients in our study. The purpose of this research was completely explained to the patient and was assured that their information will be kept confidential by the researcher. This research was approved by the ethical committee of Jahrom University of Medical Sciences issued with code No.: Jums.REC.1392.028.

\section{Consent for publication}

Consent was obtained from the patients regarding the publication of this study.

\section{Availability of data and materials}

SPSS data of the participant can be requested from the authors. Please write to the corresponding author if you are interested in such data.

\section{Competing interests}

The authors declare that they have no competing interests.

\section{Funding}

No financial support was received for this study.

\section{Authors' contributions}

Study concept and design: Rahim Raufi, Nikta Taghipour. Acquisition of data: Rahim Raufi, Seyedeh Maryam Pishva. Analysis and interpretation of data: Reza Shahriarirad, Nikta Taghipour. Drafting of the manuscript: Seyedeh Maryam Pishva, Reza Shahriarirad. Critical revision of the manuscript for important 
intellectual content: Rahim Raufi, Nikta Taghipour. Statistical analysis: Reza Shahriarirad, Nikta Taghipour. Study supervision: Rahim Raufi. All authors have approved the final version of the manuscript.

\section{Acknowledgments}

We would like to express our sincere gratitude to the Clinical Research Development Unit of Motahari Educational and Research and Therapeutic Center affiliated to Jahrom University of Medical Sciences for providing suitable environmental facilities and research requirements.

\section{References}

1. Ansari S, Yamaoka Y. Helicobacter pylori Virulence Factors Exploiting Gastric Colonization and its Pathogenicity. Toxins. 2019;11(11):677.

2. Salih B. Helicobacter pyloriinfection in developing countries: The burden for how long? Saudi J Gastroenterol. 2009;15(3):201.

3. Akopyanz N, Bukanov NO, Westblom TU, Kresovich S, Berg DE. DNA diversity among clinical isolates ofHelicobacter pyloridetected by PCR-based RAPD fingerprinting. Nucleic Acids Res. 1992;20(19):5137-42.

4. Atherton JC. The clinical relevance of strain types of Helicobacter pylori. Gut. 1997;40(6):701-3.

5. De Luca A, laquinto G. Helicobacter pylori and gastric diseases: a dangerous association. Cancer Lett. 2004;213(1):1-10.

6. Burkitt MD, Duckworth CA, Williams JM, Pritchard DM. Helicobacter pylori-induced gastric pathology: insights fromin vivoandex vivomodels. Dis Model Mech. 2017;10(2):89-104.

7. Kusters JG, van Vliet AHM, Kuipers EJ. Pathogenesis of Helicobacter pylori Infection. Clin. Microbiol. Rev.. 2006;19(3):449-90.

8. Park JB. Helicobacter pyloriinfection in gastric mucosa-associated lymphoid tissue lymphoma. World J. Gastroenterol. $2014 ; 20(11): 2751$.

9. Suerbaum S, Michetti P. Helicobacter pylorilnfection. N. Engl . J. Med. 2002;347(15):1175-86.

10. Covacci A. Helicobacter pylori Virulence and Genetic Geography. Science. 1999;284(5418):1328-33.

11. van Doorn LJ, Figueiredo C, Rossau R, et al. Typing of Helicobacter pylori vacA Gene and Detection of cagA Gene by PCR and Reverse Hybridization. J. Clin. Microbiol. 1998;36(5):1271-6.

12. Gebert B, Fisher W, Haas R. The Helicobacter pylori vacuoloating cytotoxin: from cellular vacuolation to immunosuppressive activities. Rev. Physiol. Biochem. Pharmacol. 2004. p. 205-20.

13. Yamaoka Y, Kato M, Asaka M. Geographic Differences in Gastric Cancer Incidence Can be Explained by Differences between Helicobacter pylori Strains. J. Intern. Med. 2008;47(12):1077-83.

14. Fallahi G-H, Maleknejad S. Helicobacter pylori culture and antimicrobial resistance in Iran. Indian J Pediatr. 2007;74(2):127-30.

15. Torres LE, Melián K, Moreno A, et al. Prevalence of vacA, cagA and babA2 genes in Cuban Helicobacter pylori isolates. World J. Gastroenterol. 2009;15(2):204.

16. Saribasak H, Salih BA, Yamaoka Y, Sander E. Analysis of Helicobacter pylori Genotypes and Correlation with Clinical Outcome in Turkey. J. Clin. Microbiol. 2004;42(4):1648-51.

17. Hosseini E, Poursina F, de Wiele TV, Safaei HG, Adibi P. Helicobacter pylori in Iran: A systematic review on the association of genotypes and gastroduodenal diseases. J Res Med Sci. 2012 Mar;17(3):280-92.

18. Qiao W. cagA and vacA genotype ofHelicobacter pyloriassociated with gastric diseases in Xi'an area. World J. Gastroenterol. 2003;9(8):1762.

19. Caner V. H pylori iceAalleles are disease-specific virulence factors. World J. Gastroenterol. 2007;13(17):2581.

20. Chomvarin C, Namwat W, Chaicumpar K, et al. Prevalence of Helicobacter pylori vacA, cagA, cagE, iceA and babA2 genotypes in Thai dyspeptic patients. Int. J. Infect. Dis. 2008;12(1):30-6.

21. Dabiri H, Bolfion M, Mirsalehian A, et al. Analysis of Helicobacter pylori Genotypes in Afghani and Iranian Isolates. Pol. J. Microbiol. 2010;59(1):61-6.

22. Kargar M, Souod N, Doosti A, Ghorbani-Dalini S. Prevalence of Helicobacter pylori vacuolating cytotoxin A gene as a predictive marker for different gastrodoudenal diseases. Iran J Clin Infect Dis. 2011;6(2):85-9.

23. Jafari F, Shokrzadeh L, Dabiri H, et al. vacA genotypes of Helicobacter pylori in relation to cagA status and clinical outcomes in Iranian populations. Jpn. J. Infect. Dis. 2008;61(4):290.

24. Hussein NR, Mohammadi M, Talebkhan Y, et al. Differences in Virulence Markers between Helicobacter pylori Strains from Iraq and Those from Iran: Potential Importance of Regional Differences in H. pylori-Associated Disease. J. Clin. Microbiol. 2008;46(5):1774-9.

25. Amjad N. Clinical significance ofHelicobacter pylori cagAandiceAgenotype status. World J. Gastroenterol. 2010;16(35):4443.

26. Nimri LF, Matalka I, Bani-Hani KE, Ibrahim M. Helicobacter pylorigenotypes identified in gastric biopsy specimens from Jordanian patients. BMC Gastroenterol. 2006;6(1).

27. Infection with cagA-positive $\mathrm{H}$. pylori strains is associated with gastric carcinoma risk. Nat Rev Clin Oncol 4, 678 (2007). https://doi.org/10.1038/ncponc0967

28. Nogueira C, Figueiredo C, Carneiro F, et al. Helicobacter pylori Genotypes May Determine Gastric Histopathology. Am. J. Pathol.. 2001;158(2):647-54.

29. Lu J-J, Perng C-L, Shyu R-Y, et al. Comparison of Five PCR Methods for Detection of Helicobacter pylori DNA in Gastric Tissues. J. Clin. Microbiol. 1999;37(3):772-4.

30. Atherton JC, Cao P, Peek RM, Tummuru MKR, Blaser MJ, Cover TL. Mosaicism in Vacuolating Cytotoxin Alleles ofHelicobacter pylori. J. Biol. Chem. 1995;270(30):17771-7. 
31. Yamazaki S, Yamakawa A, Okuda T, et al. Distinct Diversity of vacA, cagA, and cagE Genes of Helicobacter pylori Associated with Peptic Ulcer in Japan. J. Clin. Microbiol. 2005;43(8):3906-16.

32. Hamlet A, Thoreson AC, Nilsson O, Svennerholm AM, Olbe L. Duodenal Helicobacter pylori infection differs in cagA genotype between asymptomatic subjects and patients with duodenal ulcers. Gastroenterology. 1999;116(2):259-68.

33. Niknam R, Seddigh M, Fattahi MR, Dehghanian A, Mahmoudi L. Prevalence of Helicobacter pylori in Patients With Dyspepsia. Jundishapur J Microbiol. 2014;7(9). 